\title{
ECONOMIC CONTENT OF THE CATEGORY "PRODUCTION INVENTORIES" IN THE CONTEXT OF ORGANIZATION OF ACCOUNTING AND CONTROL IN AN INDUSTRIAL ENTERPRISE ENTERPRISES
}

\author{
Saienko O.R., Patenko I.V. \\ Zaporizhzhia National University \\ Ukraine, 69063, Zaporizhzhia, Zhukovsky str., 66 \\ Saenkohelen3@gmal.com \\ ORCID 0000-0001-8979-9354
}

Key words:

budgeting, budget, digital economy, business digitalization.
The article examines the economic category of "inventories" through the prism of the system of organization of accounting and control of industrial enterprise management. It is proved that a comprehensive approach to the interpretation of the concept of inventories is a necessary condition for the rational organization of accounting and control of production activities. The views of various scientists on the definition of the economic category "inventories" have been highlighted and on the basis of the study the author's definition of this concept has been proposed. It has been substantiated that the study of inventories in terms of means of production makes it possible to build an effective system of accounting and control of existing assets in the enterprise.

The necessity of improving the formation of information on the movement of inventories and their reflection in financial accounting is proved. As a result of the study, the approach to the formation of accounting policies of industrial enterprises in terms of inventories by expanding its structural elements to ensure the complexity of the accounting process, which leads to a qualitatively higher level of accounting procedures given the formation of financial results.

Proposals are given to determine the sequence of stages of internal control in the process of checking operations on the use of inventories in order to provide the management of the enterprise with operational information for management decisions. The solution of a set of controversial issues regarding the accounting and information provision of stocks is relevant for Ukrainian enterprises today and requires further research in order to form a more effective accounting and management model.

\section{ЕКОНОМІЧНИЙ ЗМІСТ КАТЕГОРІЇ «ВИРОБНИЧІ ЗАПАСИ» В КОНТЕКСТІ ОРГАНІЗАЦІЇ ОБЛІКУ І КОНТРОЛЮ НА ПРОМИСЛОВОМУ ПІДПРИЕМСТВІ}

\author{
Саснко О.P., Патенко I.B. \\ Запорізький національний університет \\ Украӥна, 69063, м. Запоріжжя, ул. Жуковського, 66
}

\section{Ключевые слова:}

виробничі запаси, матеріальні активи, облік, контроль, облікова політика.
У статті досліджено економічну категорію «виробничі запаси» через призму системи організації обліково-контрольного забезпечення управління промисловим підприємством. Доведено, що комплексний підхід до трактування поняття виробничих запасів $\epsilon$ необхідною умовою раціональної організації обліку і контролю виробничої діяльності. Висвітлено погляди різних науковців щодо визначення економічної категорії «виробничі запаси» та на основі проведеного дослідження запропоновано авторське визначення даного поняття. Обгрунтовано, що вивчення виробничих запасів 3 точки зору засобів виробництва дає можливість побудувати ефективну систему обліку і контролю наявних активів на підприємстві. Доведено необхідність удосконалення формування інформації щодо руху виробничих запасів та їх відображення у фінансовому обліку. В результаті проведеного дослідження оптимізовано підхід до формування облікової політики промислового підприємства в частині виробничих запасів шляхом розширення іiї структурних елементів 3 метою забезпечення комплексності облікового процесу, що обумовлює якісно вищий рівень застосування облікових процедур 3 огляду на формування фінансових результатів суб'єктів господарювання. Дано пропозиції з визначення послідовності етапів внутрішнього контролю в процесі перевірки операцій з використання виробничих запасів 3 метою надання керівництву підприємства оперативної інформації для прийняття управлінських рішень. Вирішення комплексу суперечливих питань щодо обліково-інформаційного забезпечення запасами на сьогодні $є$ актуальним для підприємств України та потребує подальших досліджень 3 метою формування більш ефективної обліково-управлінської моделі. 


\section{Formulation of the problem}

Inventories play a significant role in the economic activity of the enterprise. They ensure the consistency, continuity and rhythm of its activities and guarantee it economic security. Inventories have the largest share in the material costs of industrial enterprises. The main tool for improving the efficiency of inventory management is the rational organization of their accounting and control. Carrying out control of use of production stocks allows to increase efficiency of work of the enterprise as a whole. Defining and developing areas for improving the efficiency of economic activity of enterprises involves improving the organization of accounting and control of inventories, which will allow the company's management to obtain information to optimize management decisions.

\section{Analysis of recent research and publications}

The question of the economic essence of production stocks and the organization of their accounting and control at the enterprise was studied by such scientists and specialists in the field of economics as F.F. Butynets, P.S. Bezrukikh, V. Sonko, V. Stevenson, AA Oglobin, V.V. Ivanienko, V.M. Boyko, I.B. Shoemaker, M.S. Pushkar, I.A. Bondareva, R.F. Jacobs, I.A. Blank, etc.

Despite the large number of studies and publications, the system of accounting and control of inventories requires a more detailed definition and development of methodological approaches to its formation for further scientific and practical study.

\section{Formulation of the goals of the article}

The urgency of the problems of organization and control of production stocks of an industrial enterprise and the need for a comprehensive study of theoretical and methodological issues led to the choice of the topic of scientific work.

\section{Presenting main material}

Inventories are current assets, and according to the Law of Ukraine "On Accounting and Financial Reporting", assets are resources controlled by the enterprise as a result of past events, the use of which is expected to result in future economic benefits from any use of such inventory [1].

Stocks must meet the following characteristics:

- be the property of the enterprise;

- act in the form of tangible assets;

- be used in the production process (for manufacturing companies), or in the sales process (for manufacturing and trading companies);

- be converted into cash within a year or one operating cycle.

However, such a concept as "production inventories "Regulation (Standard) of Accounting does not contain, although the composition of stocks allocate raw materials, materials and auxiliary materials, components and other tangible assets that are intended for the manufacture of products, performance of works, provision of services, maintenance production and administrative needs [2].

In the economic literature there are various interpretations of this concept, the difference of which indicates that the disclosure of the essence of any economic category depends on the chosen approach to its definition [3]. Table 1 shows the results of a study of the economic category of "inventories" by various scientists.

Table 1 - Generalization of the results of the study of "production inventories " as an economic category

\begin{tabular}{|c|c|}
\hline Determination of production inventories & Authors \\
\hline Material resource & AS Borodkin, \\
& PS Bezrukikh, \\
& NI Verkhoglyadov, \\
& MS Bilyk, \\
& AA Oglobin \\
\hline Means of production & M.S. Pushkar, \\
& ZD Tichuk \\
\hline Tangible current assets & IB Shoemaker, \\
& VV Kовальов \\
\hline
\end{tabular}

Based on the study of methodological approaches to the interpretation of the concept of "inventories", we propose our own definition of this economic category as objects of labor intended for the production of finished products and other economic needs of the entity (construction, consumption, payment for other resources) are consumed in the production cycle and fully transfer their value to the cost of manufactured products and the use of which yields economic benefits in the future.

Many researchers believe that the incorrect organization of the availability and use of inventories have a significant impact on the financial performance of the enterprise, so it is necessary to improve the organization of inventory accounting and optimize their availability.
The main problems of accounting for inventories of enterprises include:

- incorrect determination of the initial value of purchased inventories and the difficulty of determining the fair (market and non-market) value of inventories (in the case of enterprises using barter exchange, exchange for dissimilar assets);

- the difficulty of assigning stocks to a particular group; - inexpediency of using certain methods of writing off inventories;

- unsatisfactory organization of warehousing during storage of stocks and the problem of automation of inventory.

- inadequate level of control and operational regulation of the processes of formation and use of stocks. 
Problems of accounting for inventories arise when estimating them at the balance sheet date. In accordance with Regulation (Standard) of Accounting Inventories at the balance sheet date should be measured at lower of cost and net realizable value. The amount by which the initial cost of inventories exceeds the net realizable value of inventories is deducted from the cost of the reporting period, but the value of net realizable value is quite subjective, as in practice even valuation experts find it difficult to reliably determine the expected inventory price and cost related to the sale of stocks. The basis for the assessment can be: data from price lists of enterprises-manufacturers, special studies of market price fluctuations for certain types of stocks, etc. To determine fair value and net realizable value, it is necessary to create a national base of average market prices for the most commonly used types of assets. This will allow companies to use uniform data to determine the fair value of assets.

An important condition for the correct organization of inventory accounting is their correct classification and grouping. The basic classification of stocks is laid down in the legislation, namely in the Chart of Accounts of assets, capital, liabilities and business operations of enterprises and organizations [4]. But due to the fact that enterprises use numerous different inventories, and they are used in production in different ways, this classification is not enough for large enterprises. Thus, the industrial enterprise needs its own development of the nomenclature of the stock in accordance with the peculiarities of economic activity.

Also, one of the important problems of the organization of accounting is the choice of methods for estimating inventories at their disposal. Constant changes in inventory prices and different methods of writing them off in different ways affect performance. Therefore, it is necessary to choose the optimal method of disposal of stocks, which will be justified in terms of inflation, will correspond to the production process and take into account not only current but also strategic objectives of the enterprise.

In accordance with the Regulation (Standard) of Accounting 9 item 16 "Estimation of inventory disposal" the company can use the following methods of write-off of inventories: identified cost, weighted average cost, cost of first-time inventories (FIFO), regulatory costs, selling prices. Depending on the choice of write-off method, companies have the opportunity to influence the value of the financial result. If the company aims to attract investors and creditors, the efforts will be directed to reflect in the financial statements of the maximum amount of retained earnings by underestimating the cost, by reflecting the lower cost of depreciated inventories, for example, by the FIFO method. In the case where the company is forced to hide its profits due to overstatement of production costs in order to reduce the amount of income tax, the weighted average cost method will be used.
Regarding the organization of inventory accounting, the development of the structure of accounting policy elements is of paramount importance - a list of basic provisions for inventory accounting, which are given in the order on accounting policy [5]. The source of the development of elements of the accounting policy of inventories is the Regulation (Standard) of Accounting 9 "Inventories" and guidelines for inventory accounting. From the content of the specified normative documents it is possible to define those basic provisions on the account of production stocks which need to be opened in the order on the accounting policy. Based on the analysis of regulatory documents, the structural elements of the accounting policy for the reflection in the accounting of inventories are formed (Fig. 1)

To ensure effective inventory accounting at each enterprise, a specific program of internal control over the preservation and use of material resources should be developed, which will include a detailed list of inspection issues, inspection deadlines and names of executors. Only with the help of control can the loss or damage of inventory be prevented. To ensure control over the availability and movement of stocks in the prescribed manner, it is necessary to conduct an inventory and control sample checks of residues of materials, to reflect them in time.

The system of internal control must become part of the enterprise, otherwise there is a possibility that this system will be either very expensive or inefficient [6]. A necessary condition for effective and rational management of material resources in modern economic conditions is independent control, which is carried out either by external or internal auditors, provided a properly organized system of internal control.

The main measures to control operations with inventories should be as follows:

- inspection of the organization of warehousing and the state of storage of stocks;

- verification of stock standards;

- check of observance of norms of expenses of materials, raw materials and fuel;

- checking the correctness of the reflection in the accounting of operations to write off inventories at the cost of finished products;

- verification of compliance with the tax legislation of the enterprise on transactions related to the formation of the cost of production;

- checking the correctness of the sale of surplus stocks;

- analysis of the efficiency of material resources;

- assessment of the completeness and correctness of the reflection of inventories in accounting and reporting.

Based on the study, it is recommended to conduct internal control of inventories, taking into account the sequence of these stages (Fig. 2). 


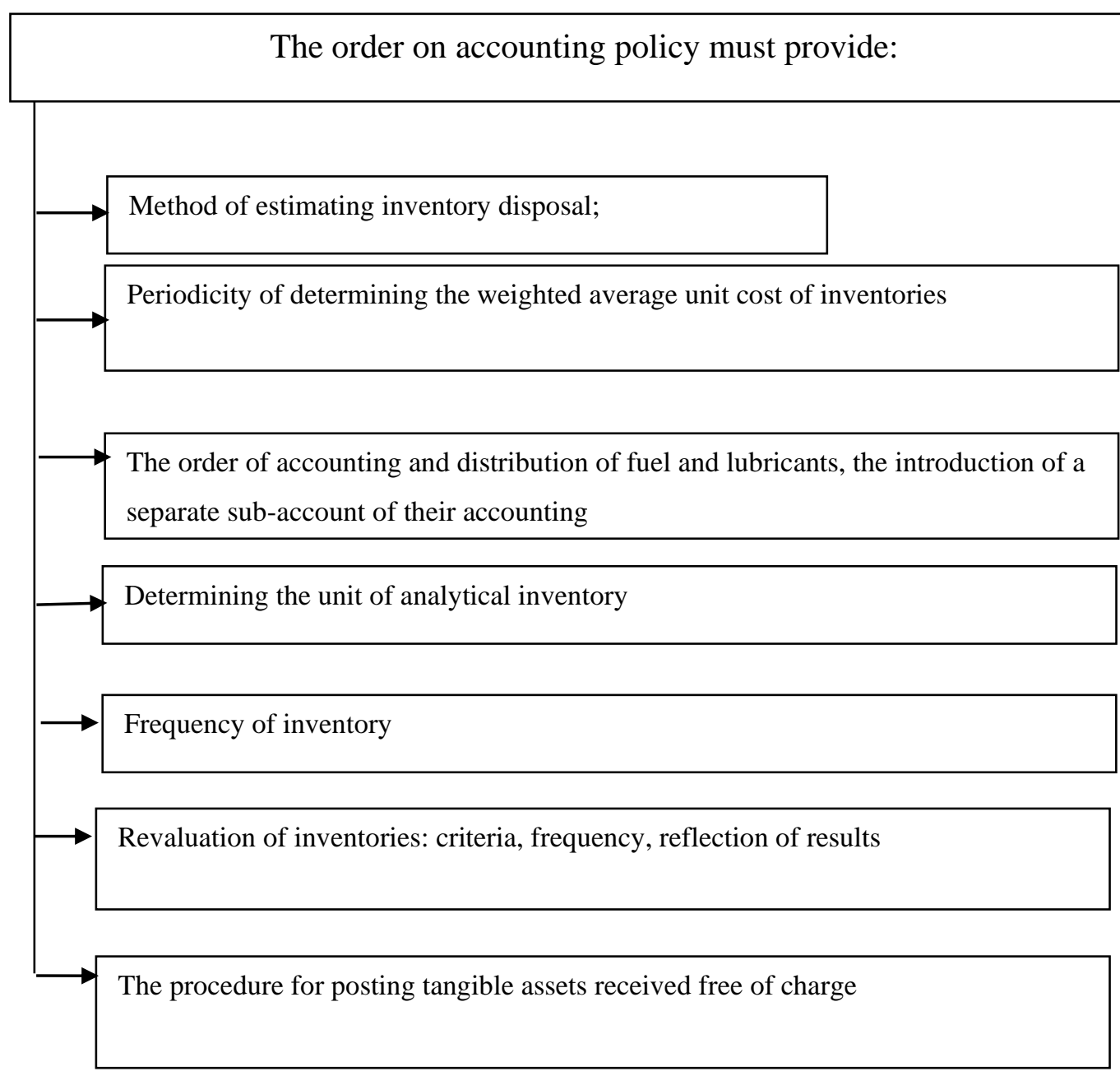

Fig. 1. The recommended structure of the elements of the accounting policy for the reflection in the accounting of inventories

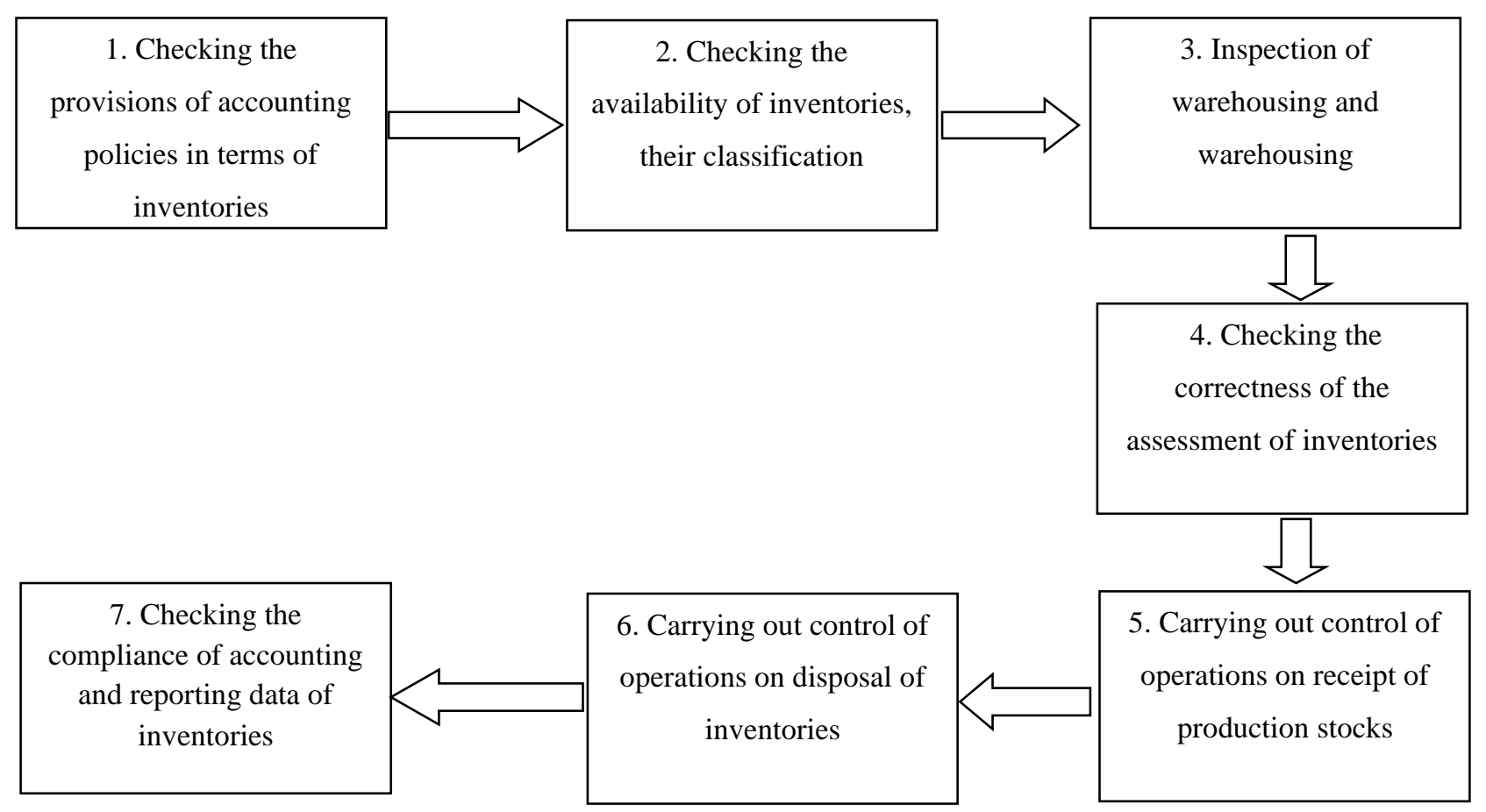

Fig. 2 The sequence of internal control of inventories

Carrying out internal control in accordance with the proposed stages will allow the industrial enterprise to form an effective policy of inventory management. 


\section{Conclusions and suggestions}

Thus, the definition of inventories as an economic category is quite multifaceted. In the system of components of the production process, they are the subject of labor, to which man directs his tools and mechanisms.

The study of the essence of the concept of "inventories" allowed us to determine that inventories are one of the key factors in the efficiency of industrial production. Their accounting and control over use are regulated by regulations.

As a result of the study of the organization of inventories, the methodological approach to the formation of accounting policies of industrial enterprises in terms of inventories by expanding its structural elements to ensure the complexity of the accounting process, which leads to a qualitatively higher level of accounting procedures given the formation of financial results of business entities.

Due to the fact that the rational use of inventories has the potential to increase production efficiency, internal control in modern economic conditions is important. The proposed methodological approach to internal control will allow the industrial enterprise to form an effective policy of inventory management.

The solution of a set of controversial issues regarding the accounting and information provision of stocks is currently relevant for Ukrainian enterprises and requires further research in order to form a more effective accounting and management model.

\section{References}

1. Pro bukhhalters'kyy oblik ta finansovu zvitnist' v Ukrayini: Zakon Ukrayiny [On Accounting and Financial Reporting in Ukraine: Law of Ukraine]. № 996-XIV - (Zakon Ukrayiny).

2. Polozhennya (standart) bukhhalters'koho obliku 9 «Zapasy»: Nakaz Ministerstva finansiv Ukrayiny [Regulation (standard) of accounting 9 "Inventories": Order of the Ministry of Finance of Ukraine]. № 246 - (Natsional'nyy standart Ukrayiny).

3. Fedak, L.M. (2012) Zapasy pidpryyemstv: sutnist' ta klasyfikatsiya [Stocks of enterprises: essence and classification] Visnyk Khmel'nyts'koho natsional'noho universytetu. Seriya: Ekonomichni nauky, vol. 1, pp. 157-162.

4. Instruktsiya pro zastosuvannya Planu rakhunkiv bukhhalters'koho obliku aktyviv, kapitalu, zobov'yazan' i hospodars'kykh operatsiy pidpryyemstv i orhanizatsiy: zatv. nakazom Ministerstva finansiv Ukrayiny [Instructions on the application of the Chart of Accounts for accounting of assets, capital, liabilities and business operations of enterprises and organizations: approved. by order of the Ministry of Finance of Ukraine].- № 291 (Normatyvnyy dokument. Instruktsiya).

5. Instructions on the application of the Chart of Accounts for accounting of assets, capital, liabilities and business operations of enterprises and organizations: approved. by order of the Ministry of Finance of Ukraine [Effective from 1999-11-30] .- № 291 - (Normative document. Instruction)

6. Nesterenko S.S. (2013) Sutnist' oblikovoyi polityky, yiyi znachennya i vymohy, problemy formuvannya ta shlyakhy yikh vyrishennya [The essence of accounting policy, its meaning and requirements, problems of formation and ways to solve them] Ekonomichni nauky. Ceriya: Oblik i finansy, vol. 10(4)., pp. $24-31$.

7. Bondarenko N. M. (2017) Orhanizatsiya vnutrishn'oho kontrolyu zapasiv na pidpryyemstvi [Organization of internal control of stocks at the enterprise] Naukovyy visnyk Mizhnarodnoho humanitarnoho universytetu. Seriya : Ekonomika i menedzhment, vol. 23(2)., pp. 97-100. 